\title{
TINGKAT KESESUAIAN KOMPETENSI INTI DAN MANAJERIAL PEJABAT PENGAWAS (ESELON IV) DI KANTOR WILAYAH KEMENTERIAN AGAMA PROVINSI KALIMANTAN TIMUR
}

\section{THE SUITABILITY LEVEL OF CORE COMPETENCIES AND MANAGERIAL COMPETENCIES OF SUPERVISOR OFFICERS (ESELON IV) IN THE REGIONAL OFFICE OF THE MINISTRY OF RELIGION, EAST KALIMANTAN PROVINCE}

\author{
Lia Rosliana dan Rustan A. \\ PKP2A III Lembaga Administrasi Negara \\ Jl. H.M Ardans (Ring Road III) Samarinda-Kalimantan Timur \\ Email : lia_rosliana2000@yahoo.com; rustanamarullah8@gmail.com \\ Naskah diterima : 17 November 2017, Direvisi : 22 Januari 2018, \\ Disetujui : 31 Januari 2018
}

\begin{abstract}
Competency is one of the driving elements that will elevate the organizational performance. The suitability between competencies required by the job and those possessed by the person performing that position will influence the level of organizational achievement and the effectiveness of task demands (Marrelli, 1998, Jackson and Schuler. 2003). Discussing competency is an interesting topic since it is concerning "the ability to do something and to manage it" (Bradley, 1991). The inability to fulfill a competency standard will undermine the performance of the job and organization. This research utilizes mixed method approach by conducting competency diagnosis toward supervisor officers (echelon IV) in the Regional Office of the Ministry of Religious Affairs of East Kalimantan Province in order to map the gap analysis of the skill in every position. Results of the study indicates that most of supervisor officers have met the expected competency standard. However, there are some officials that did not fit the competency standard. In order to improve the officers' competency (or minimize the competency gap), this study offers eight efforts that can be performed such as providing training which is relevant with the competency required, independent training, coaching, job-shadowing, giving challenge, organizational culture change, continous performance feedback, as well as assignment and apprenticeship.
\end{abstract}

Keywords: Competency, Suitability of Competency, Competency Improvement 


\begin{abstract}
Abstrak
Kompetensi merupakan salah satu faktor pendorong optimalisasi kinerja organisasi. Kesesuaian antara kebutuhan kompetensi jabatan dengan kompetensi pejabatnya akan menentukan level keberhasilan organisasi dan efektivitas tuntutan pelaksanaan tugas (Marrelli, 1998, Jackson and Schuler, 2003). Pembahasan terkait kompetensi merupakan hal yang menarik karena kompetensi adalah tentang "mampu melakukan sesuatu dan me-managenya” (Bradley, 1991). Ketidakcakapan pada suatu standar kompetensi jabatan tentu akan melemahkan capaian kinerja jabatan dan organisasi. Penelitian ini, dengan pendekatan mix method, melakukan diagnosis kompetensi pada pejabat struktural eselon IV di lingkungan Kantor Wilayah Kementerian Agama Provinsi Kalimantan Timur untuk memetakan skill gap analysis setiap jabatan. Hasil penelitian menunjukkan bahwa sebagian besar pejabat struktural eselon IV tersebut telah memenuhi standar kompetensi yang diharapkan, dan terdapat beberapa pejabat yang belum memenuhi standar kompetensi tersebut. Penelitian ini juga menganalisis delapan upaya yang dapat dilakukan untuk meningkatkan kompetensi pejabat (atau meminimalkan gap competency) tersebut. Evaluasi terhadap kesesuaian kompetensi jabatan dengan kompetensi pejabatnya perlu terus dilakukan agar pelaksanaan tugas organisasi dapat berjalan optimal disamping perlunya komitmen dan konsistensi untuk peningkatan kompetensi pegawai.
\end{abstract}

Kata Kunci: Kompetensi, Kesesuaian Kompetensi, Peningkatan Kompetensi

\title{
A. PENDAHULUAN
}

Menjadi pejabat struktural dengan segala fasilitas yang dimiliki dan prestise yang melekat menjadi idaman dan tujuan karir bagi sebagian pegawai. Namun, segala fasilitas tersebut diimbangi dengan besarnya tanggungjawab, resiko, serta span of control yang melekat dalam jabatan tersebut. Bahkan jabatan-jabatan struktural tersebut telah memberikan standar dan persyaratan kompetensi khusus untuk dipenuhi oleh para calon pemangkunya. Dengan demikian, untuk mengisi pos jabatan struktural yang tersedia bukanlah hal yang mudah, dibutuhkan sumber daya manusia yang betulbetul cakap, profesional, dan unggul.

Keselarasan antara persyaratan kompetensi jabatan dengan kompetensi pemangkunya akan melahirkan kinerja organisasi pada titik yang optimal. Keselarasan tersebut juga menguntungkan organisasi karena akan mengurangi resiko kegagalan organisasi untuk mencapai target yang ditetapkan, mampu mengembangkan fungsi organisasi melampaui pencapaian sebelumnya, serta mampu menggerakkan dan mengelola sumberdaya yang tersedia untuk meraih tujuan organisasi secara tepat.

Sriwidodo dan Haryanto (2010) dalam Sanjaya dan Indrawati (2014:207) mengemukakan pendapatnya bahwa kinerja dan keefektifan pegawai dalam melaksanakan tugas sangat ditentukan oleh kompetensi yang disyaratkan oleh bidang pekerjaan. Donzinelli, et all (2006) dalam Tripati dan Agrawal (2014:350) juga menyebutkan bahwa dengan menghubungkan proses pengelolaan sumberdaya manusia pada level kompetensi yang diharapkan, suatu organisasi dapat meningkatkan kemampuan tenaga kerjanya dan mencapai hasil yang lebih baik. Ley, et al. (2007) dalam Sanjaya dan Indrawati (2014:207) menyatakan jika kompetensi individu sejalan dengan kompetensi organisasi maka tujuan organisasi secara efektif dapat dicapai. Pencocokan kompetensi karyawan dan persyaratan kerja diklaim dapat meningkatkan kinerja karyawan dan organisasi, serta meningkatkan kepuasan (Spencer et al., 1993 dalam Agut dan Grau, 2002:32) 
Untuk mengetahui keselarasan tersebut perlu dilakukan evaluasi atas kecocokan atau kesesuaian antara tuntutan jabatan dengan kompetensi pejabat tersebut. Hasil penilaian atas kesesuaian kompetensi tersebut akan berpengaruh terhadap pengambilan keputusan pengembangan pegawai selanjutnya. Namun demikian, perlu digarisbawahi adalah upaya pengembangan dan peningkatan kompetensi pegawai ini penting dilakukan secara terus menerus agar manajemen organisasi dapat berjalan optimal.

Berdasarkan fenomena yang ada, kompetensi PNS secara umum masih dinilai relatif rendah. Kondisi PNS saat ini sebagaimana disebutkan oleh Menpan-RB bahwa sekitar 60\% PNS yang saat ini aktif hanya memiliki kemampuan administratif, dan hanya sekitar 40\% yang punya kompetensi khusus. Padahal tuntutan masyarakat akan pelayanan publik yang prima dan profesional semakin tinggi. Oleh karenanya, berbagai pendidikan dan pelatihan perlu digenjot untuk meningkatkan kompetensi keahlian PNS tersebut (Abnur, 2017).

Hal senada juga diungkapkan oleh Dwiyanto (2015, hal.100) yang menyebutkan bahwa permasalahan PNS di Indonesia adalah kompetensi bukan jumlahnya. Diungkapkan bahwa rasio PNS dan penduduk kita masih wajar bahkan lebih bagus dibandingkan negara asia lainnya hanya permasalahannya adalah kompetensi. Sehingga jika pemerintah ingin menyelesaikan masalah PNS maka pertanyaan besar yang harus dijawab adalah bagaimana caranya mempercepat arus keluar aparatur sipil negara yang tidak kompeten tersebut dan memperbesar penggantinya dengan yang lebih pantas.

Berangkat dari fenomena tersebut, perubahan image dan citra pemerintah perlu dilakukan melalui pembenahan dan penguatan kompetensi birokrasi. Penguatan kompetensi birokrasi perlu diupayakan dengan memprioritas peningkatan kompetensi aparaturnya pada setiap level jabatan sehingga knowledge, skill, dan attitude yang dimiliki dapat mendorong terciptanya organisasi pemerintah yang berdaya saing tinggi.

Salah satu agenda Reformasi Birokrasi di Kementerian Agama adalah perubahan paradigma manajemen sumber daya manusia (SDM) yang lebih efektif, transparan dan berkeadilan. Perubahan pengelolaan SDM ini diarahkan pada penerapan manajemen sumber daya manusia berbasis kompetensi (competency-based human resource management), pengelolaan fungsi-fungsi SDM secara optimal yang prosesnya didasarkan pada informasi tentang kebutuhan kompetensi dalam organisasi dan informasi tentang peta kompetensi individu pegawai. Peta kompetensi individu para pejabat struktural ini akan dijadikan sebagai acuan dalam rangka pengembangan para pejabat struktural ini agar lebih efektif dan profesional dalam rangka menjalankan tugas-tugasnya sebagai aparatur negara di Kementerian Agama. Penerapan Manajemen Sumber Daya Manusia Berbasis Kompetensi (MSDM-BK) diharapkan akan mampu mengubah dan menyempurnakan praktek rekrutmen, penempatan, pengembangan, promosi dan rotasi serta remunerasi yang dilaksanakan organisasi selama ini (Kementerian Agama, 2016 :1)

Penelitian-penelitian terdahulu terkait kompetensi diantaranya adalah penelitian Wirda dan Azra (2015) yang menggunakan analisis simple regression dengan kesimpulan bahwa kompetensi manajerial berpengaruh terhadap kinerja usaha pada industri kreatif Sumatera Barat. Kemudian Margareth dan Patrick (2000) dari penelitian survey yang dilakukan terhadap 114 perusahaan di Irlandia menemukan bahwa organisasi yang berkinerja baik cenderung menerapkan pola standar kompetensi, sehingga hasilnya juga menunjukkan bahwa organisasi atau perusahaan tersebut lebih superior dibandingkan organisasi atau perusahaan yang tidak menerapkan pola standar kompetensi tersebut. Abraham, Karns, Shaw, dan Mena (2001) dalam penelitian survey terhadap 2500 perusahaan yang dilakukan menyimpulkan bahwa organisasi yang bercita-cita menjadi organisasi berkinerja tinggi harus didorong tidak hanya untuk mengidentifikasi kompetensi manajerialnya semata 
sebagai komponen yang paling penting bagi keberhasilan organisasi, namun juga memastikan bahwa kompetensi yang sama tersebut digabungkan dalam proses penilaian kinerjanya.

Perbedaan penelitian terdahulu tersebut dengan penelitian ini adalah penulis tidak hanya mengevaluasi kompetensi manajerial saja, tetapi mengevaluasi kesesuaian kompetensi inti dan manajerial sebagai satu kesatuan dan relatif penelitian tentang evaluasi kesesuaian kompetensi inti dan kompetensi manajerial pejabat struktural masih minim dilakukan. Sedangkan metode penelitian yang dilakukan penulis adalah penelitian gabungan ( $m i x$ method) dengan responden adalah para Aparatur Sipil Negara (ASN) yang memegang jabatan pengawas (Eselon IV).

\section{Rumusan Masalah dan Tujuan Penelitian}

Kurang optimalnya pencapaian kinerja organisasi salah satunya disebabkan karena belum seimbangnya kompetensi yang dipersyaratkan suatu jabatan dengan pemangkunya. Evaluasi atas kesesuaian kompetensi tersebut menjadi penting dilakukan untuk mencapai standar kompetensi sesuai jabatan yang ditetapkan; mendapatkan peta kompetensi pegawai, dan desain program pengembangan yang disesuaikan dengan kompetensi pegawai sesuai jabatan. Berangkat dari argumentasi tersebut, rumusan masalah pada penelitian ini adalah bagaimana kesesuaian kompetensi inti dan kompetensi kepemimpinan para pejabat struktural (khususnya eselon IV) di lingkungan Kantor Wilayah Kementerian Agama Provinsi Kalimantan Timur, serta upaya-upaya apa saja yang dapat direkomendasikan untuk meminimalkan gap competency yang ada?

Tujuan penelitian ini adalah melakukan penilaian secara umum terhadap kesesuaian kompetensi inti dan kompetensi manajerial para pejabat struktural eselon IV di lingkungan Kantor Wilayah Kementerian Agama Provinsi Kalimantan Timur, untuk selanjutnya menyusun suatu model percepatan pencapaian kompetensi inti dan kompetensi manajerial yang dipersyaratkan bagi para pejabat struktural eselon IV yang belum mencapai standar yang ditetapkan.

\section{B. METODE PENELITIAN}

Penelitian ini merupakan penelitian dengan menggunakan mix method atau penelitian metode campuran. Penelitian metode campuran merupakan pendekatan penelitian yang mengkombinasikan atau mengasosiasikan bentuk kualitatif dan bentuk kuantitatif. Pendekatan ini melibatkan asumsiasumsi filosofis, aplikasi pendekatan-pendekatan kualitatif dan kuantitatif, dan pencampuran (mixing) kedua pendekatan tersebut dalam satu penelitian (Cresswell, 2012:5). Pendekatan kuantitatif dilakukan dengan menggunakan alat bantu psikologi berupa laporan test psikologi(IST/ Intelligence Structure Tes, Tes Kepribadian, Tes Grafis, Tes PAULI/ Kareplin¹ ${ }^{1}$. Tes-tes psikologi tersebut menggunakan metode kuantitatif dengan sistem scoring yang validitas dan reliabilitasnya sudah tidak diragukan lagi dan alat tes yang digunakan telah digunakan secara internasional dan diterjemahkan dalam berbagai Bahasa. Sedangkan pendekatan kualitatif dilakukan dengan cara pengumpulan data berupa laporan hasil simulasi asesmen kompetensi (Problem Analysis, Leaderless Group Discussion/LGD, observasi dan wawancara). Hasil laporan asesesmen diolah secara kualitatif dan menghasilkan laporan asesmen individual. Hasil dari laporan tes psikologi dan laporan asesmen digabung dan dianalisis kembali secara deskriptif kualitatif. Pengumpulan data dilakukan terhadap 19 pejabat struktural di lingkungan Kantor Wilayah Kementerian Agama Provinsi Kalimantan Timur yang saat ini menduduki jabatan setara eselon IV (pejabat) selama 4 bulan (September-Desember

${ }^{1}$ Tes pauli/kraepelin adalah bentuk tes berisi berbagai tahap penyelesaian kombinasi bilangan yg intinya akan menilai aspek kepribadian seseorang, kompetensi, daya tahan kerja \& lainnya (Urbina, Anne Anastasia Susana, 2010) 
2016). Adapun data dan informasi pendukung lainnya diperoleh dari sumber-sumber seperti, buku, jurnal, hasil penelitian, proceeding, serta sumber-sumber lainnya yang menunjang penelitian ini. Data-data yang diperoleh melalui proses tes psikologi dan asesmen center digabung dan dianalisis secara deskriptif kualitatif.

Penentuan sampel dilakukan secara acak bertujuan (purposive sampling). Sampel diambil pada level eselon IV karena pada level ini penguasaan teknis terhadap tupoksi yang diemban sangat dibutuhkan, disamping juga karena pada level jabatan ini secara langsung membawahi staff yang tentu memerlukan kemampuan kemimpinan yang mumpuni. Penetapan 19 orang pejabat struktural untuk dilakukan evaluasi tidak lepas dari pembagian kuota perkelompok evaluasi yang dibatasi maksimal sejumlah 19 orang, sehingga 19 orang tersebutlah yang menjadi sampel dari penelitian ini. 19 orang pejabat struktural tersebut ditetapkan secara acak mewakili masing-masing satuan kerja di Lingkungan Kantor Wilayah Kementerian Agama Provinsi Kalimantan Timur.

Jenis kompetensi yang dinilai dalam penelitian ini dibatasi pada kompetensi inti dan kompetensi kepemimpinan/ manajerial yang diharapkan dimiliki oleh pejabat struktural di lingkungan Kantor Wilayah Kementerian Agama Provinsi Kalimantan Timur. Kompetensi inti adalah “soft competency” yang wajib dimiliki oleh setiap individu pegawai Kementerian Agama yang terdiri dari, integritas, kepemimpinan, harmonisasi keberagaman, memprakarsai perubahan, serta menjaga citra kementerian agama.

Sedangkan kompetensi manajerial yaitu kompetensi kepemimpinan yang disesuaikan dengan jenjang eselon jabatan dan harus dimiliki oleh pejabat yang akan atau telah menduduki jabatan struktural tersebut. Kompetensi manajerial yang dinilai meliputi, berpikir analisis, berpikir konseptual, kerjasama, berorientasi pada pelayanan, pengambilan keputusan dan penyelesaian masalah, serta perencanaan dan pengorganisasian. Penetapan standar kompetensi inti dan kompetensi manajerial yang dianalisis disesuaikan dengan dengan Keputusan Menteri Agama No. 207 Tahun 2013 tentang Pedoman Pelaksanaan Asesmen Kompetensi bagi PNS di lingkungan Kementerian Agama dan Kamus Kompetensi Kementerian Agama.

\section{KERANGKA TEORI}

\section{Kompetensi}

Kompetensi merupakan saduran dari bahasa Inggris “competence” yang berarti kemampuan atau kecakapan. Kompetensi juga diistilahkan sebagai dimensi, dengan dasar pemikiran bahwa setiap individu memiliki karakteristik kompetensi yang tidak harus sama, sehingga bila seseorang kebetulan tidak memiliki kompetensi tertentu seperti yang diharapkan, bukan berarti orang tersebut “incompetence" (Astuti, 2006:24)

Kompetensi dapat didefinisikan sebagai karakteristik dasar seseorang yang memiliki hubungan kausal dengan kriteria diferensi efektifitas dan atau keunggulan dalam pekerjaan atau situasi tertentu. (Palan, 2008: 8). Sedangkan CIPD UK dalam Taylor (2008:25) menjelaskan bahwa kompetensi adalah sebuah pedoman dari organisasi yang diberikan kepada setiap individu untuk menghasilkan kinerja yang diharapkan. Organisasi memberikan setiap individu sebuah indikator dari sikap/ perilaku yang akan dievaluasi dan dihubungkan dengan penentuan insentifnya. Kompetensi dapat diartikan sebagai indikator kinerja suatu organisasi yang diuraikan dalam kinerja masing-masing individu di dalamnya. Marrelli (1998:8) menyebutkan "Competencies are measurable human capabilities that are required for effective work performance demands". Senada hal tersebut Jackson dan Schuler (2003) mendefinisikan kompetensi sebagai "the skills, knowledge, abilities and other characteristics that someone needs to perform a job effectively". 
Adapun kecakapan (competence) diartikan sebagai keahlian individual untuk menunjukkan pengetahuan dan keahlian dalam menghasilkan sebuah produk atau jasa sesuai standar yang diharuskan, dalam konteks tertentu, dan juga kemampuan untukmentransfer pengetahuan dan kemampuan tersebut ke konteks baru dan berbeda. Dengan pengertian yang lebih mudah, kecakapan adalah pengetahuan, keahlian dan sikap yang dibutuhkan untuk melakukan suatu pekerjaan tertentu sesuai dengan standar industri yang ditetapkan (Palan, 2008:14).

Levenson, Van Der Stede, dan Cohen (2006:2) dalam penelitiannya menemukan bahwa kompetensi secara positif berhubungan dengan kinerja ditingkat individu dan bahwa individual managerial performance dapat ditingkatkan dengan mentoring pada sistem kompetensi. Temuan senada juga disebutkan dalam hasil penelitian Sanjaya dan Indrawati (2014:207) menunjukan secara simultan kompetensi, kompensasi, dan lingkungan kerja berpengaruh signifikan terhadap kinerja karyawan. Secara parsial kompetensi, kompensasi, dan lingkungan kerja diketahui juga berpengaruh signifikan dan positif terhadap kinerja karyawan. Hal tersebut juga selaras dengan temuan penelitian yang dilakukan oleh Pattiasina dan Rumawas (2016) bahwa kompetensi sumber daya manusia memiliki hubungan yang erat dengan kinerja karyawan, apabila kompetensi sumber daya manusia yang ada dalam suatu perusahaan dapat ditingkatkan maka kinerja karyawan dapat meningkat pula.

\section{Evaluasi Kompetensi}

Evaluasi terhadap kompetensi digunakan untuk membandingkan kemampuan kandidat dengan persyaratan posisi yang ditawarkan; Begitu kandidat terbaik diidentifikasi, kesenjangan kompetensi menjadi dasar bagi rencana pembelajaran baru (Draganidis \& Mentzas, 2006 dalam Tripathi dan Agrawal, 2014:353). Diskrepansi atau gap kompetensi timbul jika kompetensi yang dimiliki seorang individu adalah lebih rendah dari yang dipersyaratkan dalam suatu posisi jabatan untuk mencapai kinerja dan keahlian tinggi (Agut and Grau, 2002) serta Boydell and Leary (1996) dalam dalam Wickramasinghe dan De Zoyza (2009:6).

Ketika kesenjangan kompetensi dapat diidentifikasi dan, jika perlu, sebuah organisasi dapat memutuskan untuk mencari solusi pengembangannya melalui strategi yang tepat seperti pelatihan, pengayaan kerja, job content innovation, redesain pekerjaan, peningkatan budaya kerja organisasi, dan lain-lain (Goldstein, 1991:507). Kompetensi dianggap sebagai karakteristik terukur seseorang yang berkaitan dengan kinerja efektif dalam pekerjaan, organisasi atau budaya tertentu. Karakteristik ini didefinisikan dalam bentuk perilaku. Karena kompetensi adalah perilaku, mereka bisa dikembangkan (Wickramasinghe dan De Zoyza, 2009:6).

Dalam penelitian ini evaluasi kompetensi dilakukan terhadap kompetensi inti dan kompetensi manajerial yang dimiliki oleh pejabat struktural di lingkungan kementerian agama. Definisi Kompetensi inti adalah sesuatu yang dimiliki perusahaan, biasanya merupakan sekumpulan keahlian dan teknologi, yang secara kolektif memberi keunggulan bersaing (Competitive advantage) suatu perusahaan (Palan, 2008:17). Sebuah Kompetensi dianggap inti, apabila kompetensi tersebut memenuhi tiga kriteria ----(Palan, 2008:17):

1. Nilai bagi pelanggan : apakah kompetensi tersebut memberi nilai yang jauh lebih tinggi bagi pelanggan?

2. Perbedaan dengan pesaing: Apakah kompetensi tersebut membedakan organisasi dalam persaingan dan membuatnya menjadi lebih unggul dari pesaing?

3. Extendability: Bisakah kompetensi inti tersebut digunakan untuk mendorong keberhasilan organisasi di masa depan. 
Berdasarkan Keputusan Menteri Agama No. 207 Tahun 2013 tentang Pedoman Pelaksanaan Asesmen Kompetensi bagi PNS di lingkungan Kementerian Agama dan Kamus Kompetensi Kementerian Agama, definisi kompetensi inti adalah kompetensi yang wajib dan mutlak dimiliki oleh setiap PNS Kementerian Agama, tanpa kecuali. Sebagai "soft competency", kompetensi inti ini merupakan gambaran dari visi, misi, dan orientasi kementerian agama yang tertuang dalam bentuk perilaku tertentu. Sedangkan definisi kompetensi manajerial adalah kompetensi sikap dan perilaku yang diperlukan untuk melaksanakan tugas dan fungsi jabatan manajerial. Asumsi yang mendasari kompetensi manajerial ini adalah keseragaman kebutuhan adanya sikap dan perilaku tertentu pada setiap tugas dan fungsi manajerial seluruh jabatan meskipun pada skala yang berbeda satu sama lainnya.

Adapun tingkatan kecakapan pada kompetensi inti dan manajerial yang diharapkan disusun dalam skala 1 sampai 5 pada tabel 1 berikut:

Tabel 1.

Tingkat Kecakapan pada Kompetensi Inti dan Manajerial

\begin{tabular}{|l|l|}
\hline Level & Makna umum \\
\hline 1 & $\begin{array}{l}\text { Mampu membina diri sendiri sehingga dapat melaksanakan tugas- } \\
\text { tugasnya }\end{array}$ \\
\hline 2 & $\begin{array}{l}\text { Mampu membina orang lain sehingga dapat melaksanakan tugas- } \\
\text { tugasnya }\end{array}$ \\
\hline 3 & $\begin{array}{l}\text { Mampu membina gugus kerja, sehingga dapat meningkatkan } \\
\text { prestasi gugus/ bagian kerja }\end{array}$ \\
\hline 4 & $\begin{array}{l}\text { Mampu membina unit kerja/ kanwil/ direktorat, sehingga dapat } \\
\text { meningkatkan prestasi gugus kerja }\end{array}$ \\
\hline 5 & $\begin{array}{l}\text { Mampu membina organisasi, sehingga dapat meningkatkan prestasi } \\
\text { organisasi }\end{array}$ \\
\hline
\end{tabular}

Selanjutnya, tingkatan kebutuhan kompetensi inti yang diperlukan untuk pejabat struktural eselon IV adalah pada level 2 sebagaimana terlihat pada tabel 2 berikut:

Tabel 2.

Level Kebutuhan Kompetensi Inti Berdasarkan Tingkatan Jabatan

\begin{tabular}{|l|l|l|l|l|l|l|}
\hline \multirow{2}{*}{ No } & \multirow{2}{*}{ Kompetensi } & \multicolumn{6}{|l|}{ Level Kebutuhan Kompetensi } \\
\cline { 3 - 7 } & & I & II & III & IV & Pelaksana \\
\hline 1 & Integritas & 5 & 4 & 3 & 2 & 1 \\
\hline 2 & Kepemimpinan & 5 & 4 & 3 & 2 & 1 \\
\hline 3 & Harmonisasi Keberagaman & 5 & 4 & 3 & 2 & 1 \\
\hline 4 & Memprakarsai Perubahan & 5 & 4 & 3 & 2 & 1 \\
\hline 5 & $\begin{array}{l}\text { Menjaga Citra Kementerian } \\
\text { Agama }\end{array}$ & 5 & 4 & 3 & 2 & 1 \\
\hline
\end{tabular}


Sedangkan tingkatan kebutuhan kompetensi manajerial yang diperlukan untuk pejabat struktural eselon IV relatif sama yaitu minimal berada pada level 2 sebagaimana terlihat pada tabel 3 berikut:

Tabel 3.

Level Kebutuhan Kompetensi Manajerial Berdasarkan Tingkatan Jabatan

\begin{tabular}{|l|l|l|l|l|l|l|}
\hline \multirow{2}{*}{ No } & \multirow{2}{*}{ Kompetensi } & \multicolumn{6}{|l|}{ Level Kebutuhan Kompetensi } \\
\cline { 3 - 8 } & & I & II & III & IV & Pelaksana \\
\hline 1 & Berpikir Analisis & $3-5$ & $3-5$ & $2-4$ & 2 & $1-2$ \\
\hline 2 & Berpikir Konseptual & $4-5$ & $3-4$ & $2-3$ & 2 & $1-2$ \\
\hline 3 & Kerjasama & $2-4$ & $2-4$ & $2-4$ & $2-3$ & $1-2$ \\
\hline 4 & Berorientasi Pada Pelayanan keputusan dan & $1-5$ & $1-5$ & $2-4$ & $2-3$ & $1-2$ \\
\hline 5 & $\begin{array}{l}\text { Pengambilan } \\
\text { penyelesaian masalah }\end{array}$ & $2-4$ & $2-4$ & $2-3$ & $1-2$ \\
\hline 6 & Perencanaan dan Pengorganisasian & $4-5$ & $3-4$ & $2-4$ & $2-3$ & $1-2$ \\
\hline
\end{tabular}

Penelitian ini selanjutnya menggunakan batasan level kebutuhan kompetensi inti dan kompetensi manajerial sebagaimana yang disebutkan dalam tabel 2 dan tabel 3 untuk menilai kesesuaian kompetensi inti dan kompetensi manajerial yang dimiliki oleh sampel pejabat struktural eselon IV di lingkungan Kantor Wilayah Kementerian Agama Provinsi Kalimantan Timur.

\section{HASIL DAN PEMBAHASAN}

\section{Gambaran Umum Responden}

Tingkat pendidikan 19 responden didominasi oleh S1 (12 orang), kemudian S2 (5 Orang), dan SLTA sebanyak 2 orang. Dari informasi ini secara jelas menunjukkan bahwa kebutuhan tingkat pendidikan untuk menjalankan tugas-tugas pejabat struktural level eselon IV sudah cukup sesuai. Namun demikian, mengingat tantangan dan kebutuhan organisasi yang semakin tinggi dibutuhkan pula peningkatan kapasitas pengetahuan dari para pejabatnya melalui pencapaian jenjang pendidikan yang lebih tinggi.

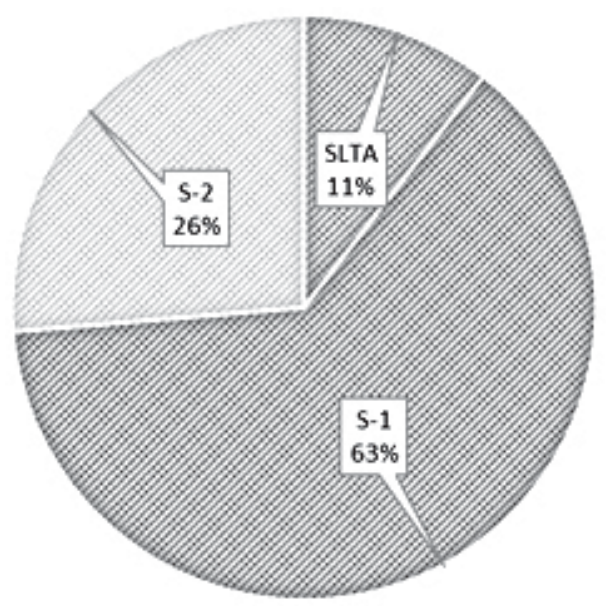

Gambar 1.

Identifikasi Tingkat Pendidikan Responden 
Dari sisi usia responden, paling rendah berumur 37 tahun dan paling tinggi berusia 56 tahun, sedangkan secara rata-rata dari 19 orang tersebut berusia 49 tahun. Data ini menunjukkan bahwa sebagian besar (12 orang atau 63,2\%) berada pada rentang usia produktif, sedangkan sekitar 7 orang (atau 36,8\%) diantaranya berapa pada rentang usia sangat produktif. Hal ini sesuai dengan pembagian penduduk usia produktif menurut BPS yang membedakan penduduk usia produktif menjadi 2 kategori, yang pertama Usia Sangat Produktif(15 - 49), dan kedua Usia Produktif (50 - 64).

Tabel 4.

Identifikasi Usia Responden

\begin{tabular}{|l|l|l|}
\hline No & Rentang Usia & Jumlah \\
\hline 1 & $\geq 37-42$ & 2 \\
\hline 2 & $\geq 43-48$ & 5 \\
\hline 3 & $\geq 49-54$ & 9 \\
\hline 4 & $\geq 55$ & 3 \\
\hline \multicolumn{2}{|l|}{ Total } & 19 \\
\hline
\end{tabular}

Berdasarkan data diatas juga dapat teridentifikasi bahwa terdapat pejabat struktural eselon IV yang sudah berada pada usia mendekati pensiun sebanyak tiga orang, dan dari tiga orang tersebut dua orang diantaranya tingkat pendidikannya masih SLTA, sehingga relatif untuk peningkatan kompetensi khususnya pada aspek pendidikan formal terhadap dua orang pejabat yang usianya 55 dan 56 tahun tersebut cukup berat untuk diwujudkan, namun pilihan peningkatan kompetensi dalam model yang lain dapat dilakukan.

\section{Hasil Evaluasi Kompetensi Inti Dan Kepemimpinan}

Dengan menggunakan hasil laporan psikotes dan laporan asesmen kompetensi, dapat diperoleh hasil evaluasi kompetensi inti dan kompetensi kepemimpinan terhadap 19 sampel pejabat struktural eselon IV atau pejabat administrator dalam tabel 5 di bawah ini. Secara umum hasil evaluasi ini membuktikan bahwa sebagian besar pejabat yang menduduki jabatan struktural tersebut telah memiliki dan memenuhi kompetensi jabatan minimal yang dipersyaratkan.

Tabel 5.

Hasil Evaluasi Kompetensi Inti Dan Kepemimpinan Terhadap 19 Sampel

\begin{tabular}{|c|c|c|c|c|c|c|c|}
\hline \multirow{2}{*}{ No } & \multirow{2}{*}{ KOMPETENSI } & \multicolumn{5}{|c|}{ TINGKAT KEMAHIRAN (LEVEL) } & \multirow{2}{*}{$\begin{array}{l}\text { Total } \\
\text { Sampel }\end{array}$} \\
\hline & & 1 & 2 & 3 & 4 & $\mathbf{5}$ & \\
\hline \multicolumn{8}{|c|}{ KOMPETENSI INTI } \\
\hline 1 & Integritas & 1 & 11 & 7 & & & 19 \\
\hline 2 & Kepemimpinan & 1 & 16 & 2 & & & 19 \\
\hline 3 & Harmonisasi Keberagaman & 1 & 13 & 5 & & & 19 \\
\hline 4 & Memprakarsai Perubahan & 9 & 9 & 1 & & & 19 \\
\hline 5 & Menjaga Citra Kementerian Agama & 1 & 16 & 2 & & & 19 \\
\hline
\end{tabular}




\begin{tabular}{|c|c|c|c|c|c|c|}
\hline \multicolumn{7}{|c|}{ KOMPETENSI MANAJERIAL } \\
\hline 6 & Berpikir Analisis & 2 & 10 & 7 & & 19 \\
\hline 7 & Berpikir Konseptual & 1 & 11 & 6 & 1 & 19 \\
\hline 8 & Kerjasama & 1 & 8 & 9 & 1 & 19 \\
\hline 9 & Berorientasi Pada Pelayanan & 1 & 10 & 8 & & 19 \\
\hline 10 & $\begin{array}{l}\text { Pengambilan Keputusan dan } \\
\text { Penyelesaian Masalah }\end{array}$ & 3 & 11 & 5 & & 19 \\
\hline 11 & Perencanaan dan Pengorganisasian & 3 & 7 & 9 & & 19 \\
\hline
\end{tabular}

Sumber : Hasil Laporan Psikotes dan Laporan Assessment, 2016

Keterangan :

:Tingkat Kemahiran yang Diharapkan

Terkait dengan hasil di tabel 5 di atas, terdapat 1 orang yang memiliki kemampuan berpikir konseptual dan kompetensi kerjasama yang diatas rata-rata atau memiliki tingkat kemahiran yang sangat tinggi (level 4) dibandingkan dengan rekan-rekan pejabat struktural lainnya. Hasil ini tentu akan menjadi salah satu catatan pelengkap untuk merekomendasikan pejabat tersebut pada jenjang jabatan yang lebih tinggi dan sesuai dengan kompetensi tersebut. Selain hasil tersebut, juga terlihat bahwa beberapa pejabat struktural memiliki tingkat kemahiran satu tingkat (level 3) diatas tingkat kemahiran minimal yang dipersyaratkan yaitu tingkat kemahiran level 2. Para pejabat yang memiliki tingkat kemahiran lebih tinggi satu tingkat diatas tingkat kemahiran minimal tersebut merupakan pejabat-pejabat potensial yang siap untuk diberikan tanggung jawab yang lebih besar sesuai dengan raihan kompetensi mereka.

Secara rinci jumlah pejabat potensial berdasarkan kelebihan setiap kompetensi yang dimiliki yaitu:

- Kompetensi inti : Kepemimpinan terdapat 7 pejabat; Kerjasama terdapat 2 pejabat; Harmonisasi keberagaman terdapat 5 pejabat; Memprakarsai perubahan terdapat 1 pejabat; dan Menjaga citra kementerian agama terdapat 2 pejabat

- Kompetensi manajerial : Berpikir analisis terdapat 7 pejabat; berpikir konseptual terdapat 6 pejabat; kerjasama terdapat 9 pejabat; berorientasi pada pelayanan terdapat 8 pejabat; pengambilan keputusan dan penyelesaian masalah terdapat 5 pejabat; dan perencanaan dan pengorganisasi terdapat 9 pejabat.

Di samping para pejabat potensial, juga terdapat beberapa pejabat yang memiliki tingkat kemahiran dibawah atau lebih rendah dari tingkat kemahiran minimal yang dipersyaratkan. Jumlah pejabat tersebut terdapat di semua komponen kompetensi, baik kompetensi inti maupun kompetensi manajerial, meskipun secara umum jumlahnya tidak banyak, namun tetap memerlukan penanganan tertentu untuk meningkatkan kompetensi mereka sehingga memenuhi syarat minimal kompetensi yang diharapkan. 
Adapun secara khusus, pada kompetensi inti yaitu memprakarsai perubahan cukup banyak pejabat (9 pejabat) yang belum mampu mencapai kompetensi minimal yang dipersyaratkan. Hasil ini tentu mengejutkan karena selain cukup banyak pejabat yang belum memenuhi, juga jenis kompetensi inti ini merupakan kompetensi yang juga sangat penting dibutuhkan untuk mendorong lahirnya inovasi dan terobosan pelaksanaan tugas. Oleh karenanya, patut menjadi perhatian bagi peningkatan kompetensi kemampuan memprakarsai perubahan tersebut melalui upaya-upaya khusus seperti mengikuti diklat berpikir kreatif dan inovatif, serta mendorong pejabat tersebut melakukan inovasi melalui perubahan budaya kerja organisasi. Dengan adanya upaya peningkatan kompetensi tersebut diharapkan diperoleh perilaku pemegang jabatan yang mampu menerima dan mengelola perubahan dengan indikator sebagai berikut:

- Sadar mengenai perubahan yang terjadi di organisasi dan berusaha menyesuaikan diri dengan perubahan tersebut

- Mampu mengidentifikasi aspek-aspek pekerjaan dan lingkungan kerja yang berubah

- Melaksanakan proses kerja baru sesuai dengan tuntutan perubahan

Pada dimensi kompetensi manajerial, jenis kompetensi yang juga masih rendah dikuasai oleh beberapa pejabat adalah kemampuan berpikir analisis, pengambilan keputusan dan penyelesaian masalah, dan perencanaan dan pengorganisasian. Untuk kompetensi berpikir analisis, dua pejabat teridentifikasi belum memiliki kemampuan mengidentifikasi dan menguraikan permasalahan sederhana secara optimal. Hal ini juga disebutkan oleh Taylor (2008:39) yang menyebutkan bahwa kompetensi berpikir analitis ditunjukkan dengan perilaku yang mampu memberikan kesimpulan atas pernyatan, membedakan informasi yang relevan untuk digunakan dalam pekerjaan, memikirkan untuk mempertahankan tujuan secara keseluruhan, Mempertimbangkan keuntungan dan resiko atas rangkaian kegiatan yang akan dilakukan. Membuat kesimpulan dari informasi yang berbeda-beda

Selanjutnya kompetensi pengambilan keputusan dan penyelesaian masalah, teridentifikasi 3 pejabat yang belum memiliki kemampuan membuat alternatif penyelesaian masalah berdasarkan hasil analisis. Kewajiban dan tanggung jawab posisi manajerial adalah diantaranya membuat keputusan yaitu : membuat keputusan bisnis tanpa ragu dalam dalam situasi yang tidak terstruktur ; memberi kewenangan untuk membuat penyimpangan dari prosedur yang telah diterapkan, baik kecil maupun besar, untuk menghadapi keadaan yang baru atau tidak biasa.(Yukl, 2015:38)

Sedangkan kompetensi perencanaan dan pengorganisasian, terdapat 3 pejabat yang belum mampu melaksanakan pengorganisasian kegiatan. Kewajiban dan tanggung jawab posisi manajerial adalah diantaranya membuat rencana dan mengorganisasi yaitu merumuskan rencana jangka pendek, melaksanakan proyek dan menyusun anggaran; menentukan alokasi dan penggunaan sumber daya secara optimal; menerjemahkan rencana jangka panjang ke dalam tujuan operasional jangka pendek; mendukung dan mengembangkan kebijakan dan prosedur operasional (Yukl, 2015:38). Adapun Taylor (2008:40) perilaku efektif dari kompetensi ini ditunjukkan dengan menyediakan waktu untuk berfikir/meninjau kembali ketika menghadapi kesulitan, memberikan perencanaan secara informal, mengamati waktu secara rutin , menyelesaikan tugas tepat waktu, mampu membedakan pekerjaan yang penting dan yang mendesak.

Terkait dengan kompetensi manajerial tersebut, dengan teridentifikasinya jenis kompetensi yang masih kurang dikuasai oleh beberapa pejabat tersebut dapat dilakukan pemetaan kebutuhan atau upaya yang dapat dilakukan untuk meningkatkan kompetensi-kompetensi tersebut. Beberapa upaya yang dapat dilakukan adalah dengan memberikan training yang relevan untuk pengembangan kompetensi tersebut, atau juga memberikan pendampingan atau coaching. Dengan adanya upaya 
tersebut, diharapkan terjadi peningkatan tingkat kemahiran mereka yang diindikasikan dengan pencapaian indikator perilaku sebagai berikut:

Tabel 6.

Jenis Kompetensi Manajerial yang Teridentifikasi Masih Kurang Dikuasai Responden

\begin{tabular}{|c|c|}
\hline Jenis Kompetensi & Indikator Perilaku Yang diharapkan \\
\hline - Berfikir Analisis & $\begin{array}{l}\text { - Menetapkan prioritas permasalahan berdasarkan } \\
\text { tingkat kepentingan } \\
\text { - Memecah persoalan menjadi bagian-bagian yang } \\
\text { dapat dikelola sistematis }\end{array}$ \\
\hline $\begin{array}{l}\text { - Pengambilan Keputusan dan } \\
\text { Penyelesaian Masalah }\end{array}$ & $\begin{array}{l}\text { - Melihat dan menganalisis suatu permasalahan } \\
\text { dari sudut pandang yang berbeda, sehingga } \\
\text { mampu menghasilkan solusi alternatif } \\
\text { - Membuat kriteria pemecahan masalah dengan } \\
\text { mempertimbangkan analisis kerugian dan } \\
\text { manfaat untuk menghasilkan alternatif solusi } \\
\text { yang baik } \\
\text { - Memecahkan masalah dengan orientasi hasil } \\
\text { yang baik di masa yang akan datang } \\
\text { - Mampu mengantisipasi resiko yang terjadi pada } \\
\text { setiap kesempatan memecahkan suatu } \\
\text { permasalahan }\end{array}$ \\
\hline $\begin{array}{l}\text { - Kompetensi perencanaan dan } \\
\text { pengorganisasian }\end{array}$ & $\begin{array}{l}\text { - Menjelaskan konsep perencanaan dasar } \\
\text { - Menjelaskan maksud dan tujuan penyusunan } \\
\text { rencana kerja dan kegiatan harian/ sederhana } \\
\text { - Menyusun rencana kerja dan kegiatan harian/ } \\
\text { sederhana. Menyiapkan alat dan bahan } \\
\text { pendukung pelaksanaan kegiatan } \\
\text { - Menyusun run down kegiatan } \\
\text { - Menyusun check list pelaksanaan kegiatan } \\
\text { - Memeriksa dan memgevaluasi dokumen } \\
\text { pendukung penyusunan rencana pelaksanaan } \\
\text { kegiatan } \\
\text { Memeriksa nun down dan check list pelaksanaan } \\
\text { kegiatan }\end{array}$ \\
\hline
\end{tabular}

Untuk mencapai indikator perilaku yang diharapkan dalam tabel 6 di atas diperlukan agenda pembenahan diantaranya perencanaan dan pemilihan jenis pengembangan kapasitas pegawai melalui alternatif-alternatif peningkatan kompetensi yang akan dijelaskan pada bagian selanjutnya. Untuk mendukung realisasi atas agenda tersebut, organisasi perlu berkomitmen untuk menyediakan dan memfasilitasi sumberdaya yang diperlukan sebagai bentuk investasi organisasi kepada pegawai (investing in people).

\section{Analisis Upaya Meminimalisir Gap Competency}

Untuk meningkatkan penguasaan kompetensi yang masih kurang, diperlukan upaya terencana dan strategis oleh organisasi untuk meminimalkan gap kompetensi yang ada. Pilihan upaya optimal yang dapat dilakukan oleh organisasi diantaranya berupa pelatihan yang relevan, maupun pengembangan non pelatihan baik penugasan, pemagangan, maupun coaching dan counselling. 
Pemilihan upaya peningkatan kompetensi akan sangat bergantung pada kondisi organisasi yang ada, kombinasi diantara pilihan yang ada sangat disarankan agar kelemahan antar pilihan dapat saling tertutupi. Secara lengkap pilihan-pilihan upaya yang dapat dilakukan untuk meminimalisir gap competency yang ada dapat dilihat pada gambar 2 berikut:

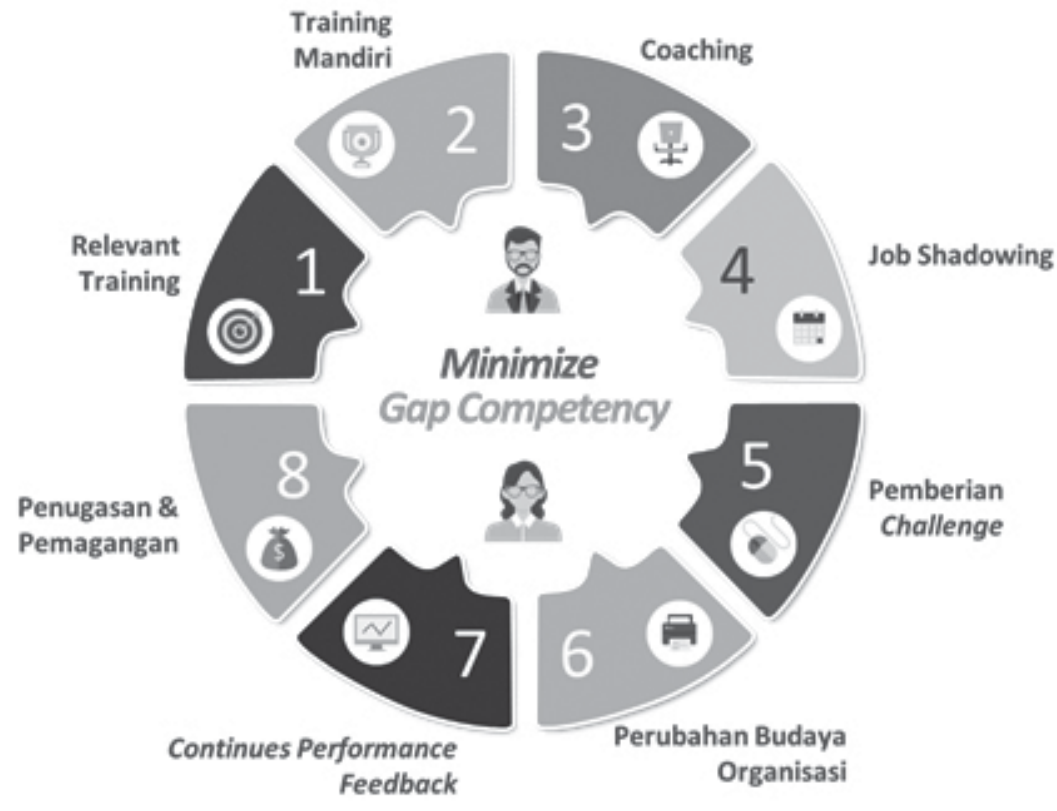

Gambar 2.

Analisis Upaya Meminimalisir Gap Competency

(Sumber : Analisis Penulis, 2017)

\section{Training yang relevan}

Upaya ini merupakan upaya konvensional yang utamanya dilakukan untuk meningkatkan kompetensi pegawai. Memberikan training yang relevan dengan pemenuhan kebutuhan kompetensi meskipun membutuhkan biaya yang cukup besar namun investasi tersebut akan memberikan dampak yang signifikan bagi kinerja dan pencapaian target organisasi. Tentu saja hasil positif ini berlaku jika pegawai tersebut mampu mengimplementasikan dengan tepat ilmu yang diperoleh dan didukung oleh lingkungan kerja yang kondusif.

2. Training mandiri

Pilihan upaya ini relatif sangat bergantung pada motivasi pribadi pegawai untuk secara sadar mengetahui kelemahan kompetensi yang dimiliki dan kemudian secara intensif memperbaiki atau meningkatkan kompetensi tersebut. Untuk mendukung training mandiri ini, organisasi perlu menyediakan sumberdaya yang dibutuhkan dalam berbagai bentuk seperti, seminar-seminar pembelajaran, program e-learning, manual-manual (petunjuk teknis), buku-buku, artikel-artikel, dan lain-lain.

3. Coaching

Cara sederhana dan murah untuk meningkatkan kompetensi karyawan adalah melalui regular coaching sessions. Sebenarnya coaching tidak serta merta mengajarkan keterampilan baru, namun teknik ini memberikan umpan balik dan bantuan konstruktif untuk memperbaiki kemampuan pegawai saat ini. Hal ini memungkinkan karyawan untuk berkinerja mencapai batas terbaik dari kemampuan mereka, serta membuka pintu untuk kesempatan belajar lebih banyak ketika mereka memiliki dasar yang kuat (Saez, 2017) 


\section{Job Shadowing}

Job shadowing adalah praktik umum yang dilakukan bagi karyawan baru, namun praktek ini berlaku atau sama efektifnya dengan pegawai yang sudah ada dan ingin maju. Kuncinya di sini adalah mengidentifikasi para top performers dan meminta pegawai yang ingin meningkatkan kompetensinya untuk turut mengamati cara kerja top performers tersebut bila memungkinkan. Pada saat yang bersamaan, orang-orang yang dibayangi tersebut secara langsung ataupun tidak langsung mendapatkan kesempatan untuk melatih orang lain (yang merupakan sebuah kompetensi baru dalam dirinya sendiri). Pegawai juga dapat membayangi (shadowing) rekan kerja mereka yang menempati posisi yang lebih tinggi dalam organisasi agar mereka memperoleh pengetahuan apa yang mereka lakukan dan bagaimana mereka pada akhirnya mampu untuk mencapai level atau posisi yang sama (Saez, 2017)

5. Pemberian Challenge

Menambahkan elemen tantangan dalam pekerjaan pegawai akan mendorong pegawai untuk melakukan hal baru serta memaksa mereka untuk mempertajam keterampilan mereka saat ini, sekaligus secara simultan menambah atau membentuk kompetensi yang baru. Upaya ini dapat dilakukan melalui berbagai cara seperti memberikan project khusus, memimpin tim, dan lainlain (Saez, 2017). Upaya memberikan challenge ini juga efektif jika organisasi memberikan insentif, bonus, awards, penghargaan, dan lain-lain sehingga mendorong pegawai untuk secara cepat mengembangkan kompetensi mereka.

6. Perubahan Budaya Organisasi

Kompetensi pegawai cenderung terhambat karena budaya kerja organisasi yang menghambat, penuh rigiditas, minim apresiasi, dan pragmatis. Oleh karenanya, diperlukan perubahan budaya organisasi yang mengajak seluruh komponen di dalamnya untuk bekerja dengan pola kerja yang baru, saling memampukan, saling mengapresiasi, knowledge sharing, mendorong pengembangan iklim organisasi yang berbasis kompetensi, serta mendukung inovasi kerja yang tercipta. Perubahan budaya kerja organisasi ini akan memunculkan kompetensi-kompetensi pegawai yang sebelumnya tersembunyi dan terhambat. Perubahan budaya organisasi merupakan pilihan peningkatan kompetensi yang sangat penting dan memerlukan dukungan dan komitmen kuat pimpinan maupun rekan kerja untuk memuluskan keberhasilannya.

7. Continues Performance Feedback

Agar dapat meningkatkan kapasitas dan kapabilitas yang dimiliki, pegawai tentu memerlukan feedback atas kinerja yang telah dilakukan. Adanya feedback secara berkelanjutan akan menjadi catatan khusus bagi pegawai untuk membenahi kompetensi yang masih lemah dalam dirinya. Hal penting yang perlu diingat bahwa penilaian atas performance dan feedback yang diberikan harus dan perlu dilakukan secara transparan dan secara objektif. Selain itu, standar dalam penilaian performance perlu disosialisasikan agar pegawai mengetahui dan memahami aspek yang dinilai dan mulai terus menerus meningkatkan kompetensinya. Pada dimensi yang lain, perlu dilakukan evaluasi terhadap performance feedback yang diberikan dengan upaya perbaikan atau perubahan yang dilakukan oleh pegawai tersebut agar dapat ditentukan upaya atau pendekatan lain untuk meningkatkan kompetensi pegawai tersebut.

8. Penugasan dan Pemagangan

Pilihan lain yang juga dapat dilakukan adalah memperbanyak pemberian penugasan kepada pegawai sesuai dengan ruang lingkup tugasnya. Kurangnya pengalaman atau “jam terbang” menjadi salah satu faktor pegawai belum mencapai kompetensi yang diharapkan. Semakin seringnya penugasan diberikan juga akan memberikan pengetahuan dan wawasan baru yang membentuk penciptaan kompetensi baru seperti kemampuan menjalin hubungan kemitraan 
dengan pihak lain, pengorganisasian suatu kegiatan, hingga kemampuan emosional. Selain penugasan, pemagangan pegawai di tempat yang berhasil atau role model juga perlu dilakukan untuk mempercepat peningkatan kompetensi pegawai maupun untuk memenuhi kebutuhan kompetensi yang diharapkan organisasi. Pemagangan memang membutuhkan durasi waktu yang relatif lama, namun demikian efek peningkatan kompetensi pegawai yang dimagangkan akan cepat meningkat dan nyata terlihat sebab mereka belajar dari tempat terbaik dan orangorang terbaik. Sekembalinya ke organisasi semula, pegawai tersebut perlu dioptimalkan terkait pemanfaatan pegawai tersebut dan kompetensi yang telah dimiliki bagi kepentingan organisasi.

Delapan pilihan upaya meningkatan kompetensi pegawai atau upaya meminimalkan gap competency antara jabatan dan pemangku jabatannya tersebut menjadi bahan penting bagi organisasi yang menginginkan pencapaian kinerja yang optimal, disamping juga bentuk kepedulian organisasi terhadap pegawainya yang hendak maju dan mengaktualisasikan dirinya bagi kemajuan organisasi secara agregat.

\section{E. PENUTUP}

\section{Kesimpulan}

Berdasarkan hasil pembahasan dan analisis yang dilakukan dapat disimpulkan beberapa hal sebagai berikut:

1. Tingkat kesesuaian kompetensi inti dan kompetensi kepemimpinan para pejabat struktural (khususnya eselon IV) di lingkungan Kantor Wilayah Kementerian Agama Provinsi Kalimantan Timur sudah sangat tinggi. Sebagian besar pejabat struktural sudah memiliki kompetensi yang dipersyaratkan oleh jabatan yang disandangnya, bahkan beberapa diantaranya memiliki level kompetensi yang lebih tinggi. Meskipun demikian, terdapat sebagian kecil pejabat struktural yang belum menguasai beberapa kompetensi inti dan kompetensi manajerial.

2. Terdapat delapan alternatif upaya yang dapat dilakukan untuk meminimalkan gap competency yang ada yaitu, pemberian training yang relevan dengan kebutuhan kompetensinya, training mandiri, coaching, job-shadowing, pemberian challenge, perubahan budaya organisasi, continous performance feedback, serta penugasan dan pemagangan.

\section{Rekomendasi}

Adapun solusi alternatif lanjutan yang dapat dilakukan untuk mendorong peningkatan kompetensi pegawai khususnya pejabat struktural adalah sebagai berikut:

1. Evaluasi terhadap kesesuaian kompetensi antara kebutuhan jabatan dengan kompetensi pejabat yang memangkunya perlu terus dilakukan agar pencapaian tugas pokok dan fungsi organisasi dapat tercapai dengan optimal. Bahkan evaluasi kompetensi tersebut perlu diberlakukan kepada seluruh pegawai secara rutin sebagai sarana untuk mengevaluasi perkembangan kompetensi pegawai dan bahan masukan bagi pimpinan untuk melakukan upaya-upaya peningkatan kompetensi pegawai dan pejabatnya.

2. Para pegawai-pegawai potensial perlu dipersiapkan dan dikaderisasi sejak dini untuk menggantikan pejabat yang belum memenuhi standar kompetensi yang diharapkan. Perubahan kebutuhan organisasi serta meningkatnya iklim kompetisi menuntut organisasi untuk dapat cepat beradaptasi, oleh karenanya dibutuhkan pejabat-pejabat yang mampu mengupgrade kompetensinya secara cepat pula. 
3. Upaya peningkatan kompetensi pegawai memerlukan komitmen dan konsisten pimpinan. Hal ini termasuk dukungan kesiapan anggaran pengembangan pegawai yang perlu dipersiapkan dan direncanakan dengan akurat. Disamping itu, organisasi juga perlu menyediakan dan memfasilitasi sumberdaya pelengkap yang diperlukan untuk meningkatkan kompetensi pegawai tersebut.

\section{DAFTAR PUSTAKA}

Abnur, Asman. (2017, July 6). 60 Persen PNS Tak Punya Kompetensi. Retrieved November 15, 2017, From JPPN :https://www.jpnn.com/news/60-persen-pns-tak-punya-kompetensi.

Abraham, Steven E., Karns, Lanny A., Shaw, Kenneth., and Mena, Manuel A. (2001). Managerial Competencies and The Managerial Performance Appraisal Process. Journal of Management Development, 20 (10), 842-852

Agut, Sonia., dan Grau, Rosa. (2002). Managerial Competency Needs and Training Requests : The Case of The Spanish Tourist Industry. Human Resource Development Quarterly, 13 (1), 31-51

Astuti, Syah Ayu Lestari Windi. (2006). Penciptaan Sistem Penilaian Kinerja yang Efektif Dengan Assessment Centre. Jurnal Manajemen, 6 (1), 23-34

Bradley, J. (1991). Competence In Managers. Management Research News, 14 (7/8/9), 39-42.

Cresswell, John W. (2012). Research Design Pendekatan Kualitatif, Kuantitatif, dan Mixed. Yogyakarta: Pustaka Pelajar.

Dwiyanto, Agus. (2015). Reformasi Kontekstual. Yogyakarta: Gadjah Mada Press.

Goldstein, I.L. (1991). Training In Work Organizations. Handbook of Industrial and Organizational Psychology, Vol. 2, Consulting Psychologists Press, California.

Jackson, S.E. and Schuler, R.S. (2003), Managing Human Resources through Strategic Partnerships, 8th ed., South-Western, Mason, $\mathrm{OH}$.

Kementerian Agama Republik Indonesia. (2015). Kamus Kompetensi Jabatan. Jakarta: Kemenag RI

Levenson, Alec R., Van Der Stede, Wim A., Cohen, Susan G. (2006). Measuring The Relationship Between Managerial Competencies and Performance. Journal of Management, 32 (3), 360-380

Margaret M. Heffernan, Patrick C. Flood. (2000). An Exploration of The Relationships Between The Adoption of Managerial Competencies, Organisational Characteristics, Human Resource Sophistication and Performance In Irish Organisations. Journal of European Industrial Training, 24 (2/3/4), 128-136. doi.org/10.1108/03090590010321098

Marrelli, A.F. (1998). An Introduction To Competency Analysis and Modeling. Performance Improvement, Vol. 37, pp. 8-17.

Palan, R. (2008). Competency Management, Teknik Mengimplementasikan Manajemen SDM Berbasis Kompetensi dan Daya Saing Organisasi. Jakarta: PPM

Saez, Alex. (2017, November 6). Ways To Improve Competency. Retrieved November 15, 2017, from Small Business: http://smallbusiness.chron.com/ways-improve-competencies-55849.html 
Sanjaya, I Kadek Edy, Indrawati, Ayu Desi. (2014). Pengaruh Kompetensi, Kompensasi, dan Lingkungan Kerja Terhadap Kinerja Karyawan Pada PT. Pande Agung Segara Dewata. EJurnal Manajemen Universitas Udayana, 3 (1), Januari. 2014.

Taylor, Ian. (2008). Measuring Competency for Recruitment and Development, Panduan Assessment Center dan Metode Seleksi. Jakarta: PPM

Tripathi, Kaushiki., dan Agrawal, Manisha. (2014) Competency Based Management In Organizational Context : A Literature Review. Global Journal of Finance and Management, 6 (2), 349-356

Urbina, Anne Annastasia Susana. (2010). Tes Psikologi. Jakarta: PT. Index

Wickramasinghe, V., dan De Zoyza, N. (2009). AComparative Analysis of Managerial Competency needs Across Areas of Functional Specialization. Journal of Management Development, 28 (4), 344-360. doi: 10.1108/02621710910947371

Wirda, Fisla dan Azra, Tuti. (2015). Kompetensi Manajerial dan Pengaruhnya Terhadap Kinerja Industri Kreatif Sumatera Barat”. Proceeding. Seminar Nasional Ekonomi Manajemen Dan Akuntansi (Snema) Fakultas Ekonomi Universitas Negeri.

Yukl, Gary. (2015). Kepemimpinan Dalam Organisasi. State University of New York at Albany: Penerbit Indeks 
